\title{
Cities, Europeanization and Multi-level Governance: Governing Climate Change through Transnational Municipal Networks*
}

\author{
KRISTINE KERN \\ Wageningen University, The Netherlands \\ HARRIET BULKELEY \\ Durham University
}

\begin{abstract}
This article focuses on a variant of multi-level governance and Europeanization, i.e. the transnational networking of local authorities. Focusing on local climate change policy, the article examines how transnational municipal networks (TMNs) govern in the context of multi-level European governance. We find that TMNs are networks of pioneers for pioneers.
\end{abstract}

\section{Introduction}

In recent years, much has been made of the growing 'multi-level' and 'network' character of European governance. In this article we focus on one variant of such governing processes, the transnational networking of local authorities. Transnational municipal networks (TMNs) are a particularly interesting subject of investigation because they have a long tradition dating back to the 13th century in the High Middle Ages (e.g. the Hanseatic League) and are an increasingly prominent feature of European governance (Ewen and Hebbert, 2007). TMNs have three defining characteristics. First, member cities are autonomous and free to join or leave. Second, because they appear

\footnotetext{
* We gratefully acknowledge the financial support of the Anglo-German Foundation. We thank the anonymous reviewer for helpful comments on a previous version of this article and Stefan Niederhafner, Sandra Rechlin and Jost Wagner for research assistance. Please note that the views expressed in this report are exclusively those of the authors. 
to be non-hierarchical, horizontal and polycentric, such networks are often characterized as a form of self-governance. Third, decisions taken within the network are directly implemented by its members. In this respect TMNs differ considerably from traditional associations or transnational NGOs which concentrate on lobbying and mobilization. While the role of local authorities in European integration has been discussed more frequently in acknowledgement of the growing multi-level character of European governance (John, 2000; Le Galès, 2002), the emergence of TMNs has been widely neglected. Most studies which mention such networks do not focus on them (John, 2000, p. 888; Marshall, 2005, pp. 680-1), but tend to consider them solely in terms of their role as lobbying agencies (Bennington and Harvey, 1998; Ward and Williams, 1997, p. 440), ${ }^{1}$ and pay little attention to their internal dynamics.

This article takes a different perspective. We examine how networks govern in the context of multi-level European governance under the conditions of Europeanization and assess the factors which determine their governing capacity. Do TMNs make a difference at European, national and local level? Addressing such issues involves engaging with the theories of both Europeanization and network governance. We argue that the development of TMNs in Europe is part of a wider process of Europeanization. In order to understand the nature and function of TMNs, we suggest that it is necessary to go beyond current network theories and to engage more explicitly with the issue of what networks do and how they achieve outcomes. To examine these issues in depth, we concentrate on a specific type of TMN, i.e. those that focus on climate protection - the Climate Alliance, Cities for Climate Protection and Energie-Cités. While some of the features of these networks are distinctive, we suggest that, due to the simultaneous emergence of a range of similar networks in different policy areas and the links to wider dynamics of Europeanization, the processes underlying the development and operation of these networks have a more general applicability (Kern, 2001; Keiner and Kim, 2007; Kern and Löffelsend, 2008; Heinelt and Niederhafner, 2008).

In addition to conducting interviews with representatives of these networks and carrying out analysis of them, the research project also included case studies on three selected local authorities in the UK (Kirklees, Leicester and Southampton) and three in Germany (Frankfurt am Main, Heidelberg and Munich). These local authorities can be considered as 'leaders' in terms of their development regarding local climate change strategies (Bulkeley and Kern, 2006); each of them has been a member of multiple climate protection networks over the past decade.

\footnotetext{
${ }^{1}$ Research on the changing role of cities and towns within European multi-level governance and the emergence of TMNs also tends to concentrate on a single policy area, namely the EU's Structural Funds (John, 2000; Schultze, 2003; Goldsmith, 2003; Marshall, 2005).
} 
Our study reveals that several factors are particularly significant in shaping the internal and external governing capacities of these networks. Based on the analysis of the various forms of governing capacities and how they are interrelated, fundamental differences between active and passive network members become evident because passive member cities are difficult to reach via the networks. Although our findings suggest that TMNs are a new and emerging form of Europeanization, they appear to be primarily networks of pioneers for pioneers.

Section I of the article focuses on the changing role of cities in European multi-level governance and how they are affected by Europeanization. The structures and functions of TMNs in Europe and the climate change case studies are described in the second section. Section III discusses different forms of governing climate change through TMNs. Based on a comparison of the three networks, we analyse the different forms of internal governing capacities as well as the different means by which TMNs operate within the context of multi-level governance. In conclusion, we discuss the factors that appear to play a decisive role in the governing capacities of TMNs and consider the implications for our understanding of the dual process of multilevel governance and Europeanization.

\section{Cities, Europeanization and Multi-level Governance}

The emergence of TMNs in Europe both reflects and constitutes two phenomena: the multi-level nature of European governance and the dynamics of Europeanization. To address first the issue of multi-level governance, as many commentators have noted, the EU has developed into a system with multiple levels or spheres of governance, including European, national and subnational policy arenas (Hooghe and Marks, 2003; Bache and Flinders, 2004; Bache, 2008). The concept of multi-level governance can be read in a narrow way as shifting competencies between local, national and supranational governmental institutions, or it can take into account not only traditional methods of public regulation by the state, but also the entire range of actions and institutions which provide order (including public-private partnerships, nonstate actors and so on). Authority has not simply shifted upwards to European institutions, it has become dispersed across multiple territorial levels and among a variety of private and public actors (Rosamond, 2007). This includes the transfer of authority from the national to the sub-national level (Pierre and Peters, 2000, p. 77) because in many European countries government has been increasingly decentralized and local competencies expanded. In the resulting governance landscape, boundaries between different arenas of 
politics have been blurred to the point of insignificance because many policy actors are able to become active at different levels and pursue multi-level strategies such as venue shopping (Baumgartner and Jones, 1993; Rosamond, 2007, p. 129; Repetto, 2006; Birkland, 2007, pp. 69-70). ${ }^{2}$ TMNs have adapted to the opportunity structure provided by the European Union's multilevel system, which provides access to key decision-makers and resources (Ladrech, 2005, p. 322).

The debate on Europeanization (Olsen, 2002; Featherstone and Radaelli, 2003; Schimmelfennig and Sedelmeier, 2005; Radaelli, 2006; Börzel and Risse, 2007; Graziano and Vink, 2007; Bache, 2008) complements the analysis of the European multi-level system by providing a sense of the means by which multi-level governance is accomplished (Pollack, 2005, p. 384). Europeanization encompasses not only the domestic impact of European-level institutions but also the impact of the EU Member States' actions on EU institutions. These top-down and bottom-up dynamics (Ladrech, 2005, p. 319) are not limited to the relationship between the EU and its Member States: these dynamics are also relevant to the relations between EU institutions and local authorities (Schultze, 2003; Marshall, 2005, p. 671; Marshall, 2008). First, the EU's legal and financial instruments have an impact on local authorities (top-down vertical Europeanization). A prominent example of this is environmental and sustainable development policy because EU decisionmaking has become far more important than domestic policy-making in this policy area. Second, local authorities have begun to influence EU decisionmaking not only indirectly by lobbying at the national level through their national associations but also directly at the European level (bottom-up vertical Europeanization) (Rechlin, 2004; Heinelt and Niederhafner, 2008). Third, European cities and towns are becoming more Europeanized because they co-operate transnationally, exchange experiences and jointly develop innovative solutions for problems with which they are similarly confronted (horizontal Europeanization).

While associations of municipalities have become increasingly Europeanized since the 1950s - witness the founding of the Council of European Municipalities and Regions (CEMR) in 1951 - since the mid-1980s numerous new organizations (such as Eurocities), which are based on the direct membership of cities rather than the representation of national associations, have supplemented the CEMR. This development can be explained by the fact that there were almost no (direct) impacts of European legislation on subnational governments before the Single European Act of 1986. This situation

\footnotetext{
${ }^{2}$ This is the case, at least, for most first-pillar issues. However, the role of the nation-states remains strong in the second and third pillars.
} 
had changed fundamentally by the early 1990s and there is now almost no area of local or regional policy which is not affected by European regulation (John, 2000, p. 879; Woll, 2006, p. 458).

TMNs become Europeanized because they adapt their organizational structures to EU decision-making structures. For example, TMNs open offices in Brussels (Ercole et al., 1997, p. 231; Goldsmith, 2003, p. 124; Kassim, 2005, p. 307), co-operate with each other to strengthen their influence and solicit EU funding. At the same time, EU institutions - in particular the European Commission - have become progressively more dependent on interest groups, using them as external sources of information and expert advice, and thus facilitating their access to European institutions (Goldsmith, 2003, p. 121; Eising, 2004; Heinelt and Niederhafner, 2008). Moreover TMNs can help the Commission to implement EU policies because they do not limit their activities to the aggregation and pursuit of their constituents' interests but also stimulate the exchange of best practice and other experiences between cities, and even develop their own standards which they require their member cities to implement accordingly.

TMNs are therefore a potentially important constituent of both the structure of European multi-level governance and its dynamics. However, the nature and extent of the significance of TMNs within the EU system depends to a large part on whether and how such networks are engaged in governing processes. In order to analyse how and with what effect TMNs govern, it is necessary to consider how such processes could be conceptualized. In previous accounts TMNs have been variously labelled as intergovernmental (Rhodes, 1997; Ward and Williams, 1997), inter-urban (Leitner and Sheppard, 2002) or simply transnational (Bennington and Harvey, 1998) networks. In all cases explicit or implicit reference is made to the concept of policy networks as providing a framework for analysis (Ward and Williams, 1997, pp. 442, 460).

We suggest, however, that a policy network approach provides an inadequate framework for analysing the nature, role and impact of TMNs for three reasons. First, whereas TMNs are comprised of municipalities and a secretariat, policy networks usually consist of a heterogeneous mix of actors (Pattberg, 2007; Khagram and Ali, 2008). Second, in the main, policy networks are considered to be linked by resource interdependencies; while resources certainly provide some of the glue which holds TMNs together, network relations are characterized more by cognitive than bargaining processes (Börzel, 1998). Finally, in the literature on policy networks there is some confusion as to what networks actually do, with emphasis usually placed on trying to influence the behaviour of a (single) central state actor, whereas TMNs undertake a variety of governing activities, including forms of 
self-governing and external influence. Other network concepts, which have been employed in the analysis of the governance of global environmental issues, also seem inadequate for the task of assessing TMNs (Betsill and Bulkeley, 2004) because the latter cannot be labelled as transnational advocacy coalitions (Keck and Sikkink, 1998) or expert epistemic communities (Haas et al., 1993). Our contention is, therefore, that in order to understand TMNs as part of the multi-level European governance we need to move beyond existing models and engage more explicitly with what networks do and how they achieve their goals. First, however, we provide further detail on the structure of TMNs in Europe and introduce our empirical case studies.

\section{Transnational Municipal Networks in Europe}

As indicated above, the marked increase in transnational networking among municipalities started in the late 1980s (Ward and Williams, 1997, p. 454). For example, Eurocities represents around 120 large cities in over 30 European countries; in the Baltic Sea Region, the Union of the Baltic Cities has a current membership of around 100 cities in all ten countries surrounding the Baltic Sea; the Alliance in the Alps is a network comprising about 250 local authorities and covering the entire Alpine region from France to Slovenia. Most of these networks concentrate on two goals: they represent the interests of their members, at European level in particular, and they facilitate the exchange of experience and transnational learning among their constituents. In the 1990s, European TMNs were characterized by dynamic growth and strong differentiation. More recently many networks have entered a different phase in their life cycle. There are some signs of stagnation, but the membership of most networks has stabilized. In addition to these general trends, TMNs, such as Eurocities and the Union of the Baltic Cities, share specific structural and functional similarities, albeit with some marked differences.

\section{The Structures and Functions of Transnational Municipal Networks}

Three groups of actors can be identified in most TMNs: (1) an international secretariat and national/sectoral co-ordinators; (2) a Presidency, Board and General Assembly; and (3) member cities (see Figure 1). The secretariat, which consists of a secretary or managing director and his or her staff, assumes the functions related to the internal governing of the network, including day-to-day routines, but is also in charge of external relations. One trend in the development of networks has been the formation of sub-networks, which specialize in a specific territory (usually that of a nation-state) or a specific policy area. National co-ordination offices have been established in 
Figure 1: Structure of Transnational Municipal Networks

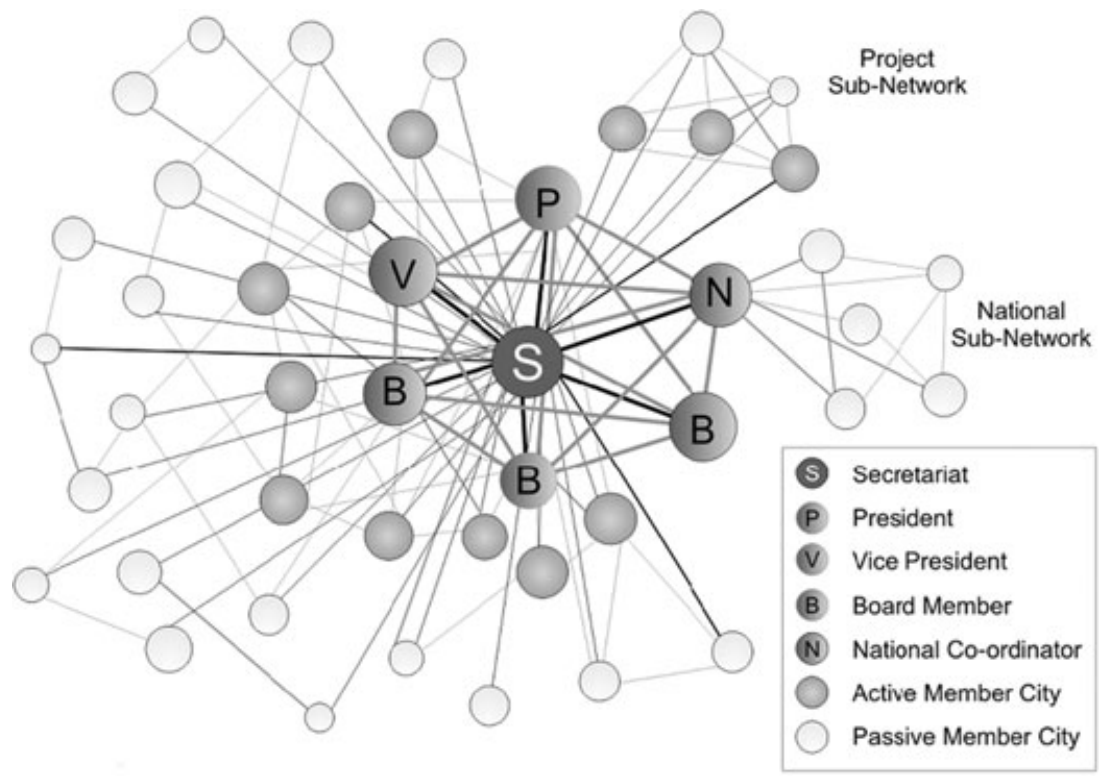

Source: Authors' own data.

some networks, while in others, the organizational structure is mainly based on policy co-ordination offices. Furthermore, some project-oriented subnetworks (usually with only a limited number of participating cities), which are supported by special EU funding, have emerged within most networks.

The second common structural feature of TMNs is that they are headed by (political) boards consisting of a president, various vice-presidents and additional board members. These bodies are responsible for general decisionmaking between General Assembly meetings. Board members represent their city and are directly involved in local politics and policy-making. Board members are usually powerful representatives (for example a mayor or vicemayor) of the most active cities who push innovative approaches at local level. They share a common interest in transnational learning and the exchange of experience across national borders. Furthermore, board members represent the network externally, for example, at international conferences, and may even engage in direct lobbying, such as in the decision-making processes of the European Commission or the European Parliament.

The third feature of TMNs is their member cities. Joining a TMN is seen to have advantages for cities, ranging from the exchange of experience to access to funding and the development of direct links between the local and 
the European levels. The representatives of the most active cities, which are often founding members of the network, participate in meetings of the General Assembly, contact the secretariat relatively frequently and build the necessary bridges between the relevant local policy networks and the secretariat and/or board. Policy changes on the ground depend on the existence of such network brokers or policy entrepreneurs (Mintrom, 2000; Kingdon, 2003, p. 279; Zahariadis, 2003) who connect the TMNs with the local policy network. In large networks like the Climate Alliance, the majority of the member cities are relatively passive. Membership in this case may be only symbolic - for instance, a city may have joined the network only after or because neighbouring cities, similar cities or sister cities did so.

Despite their structural similarities the functional specialization of these organizations can differ considerably. While peak associations like the CEMR or networks like Eurocities or the Union of the Baltic Cities cover all important local authority functions, other networks restrict their activities to a specific policy field. In recent years TMNs have become more specialized. One major reason why specialized municipal networks form is that many cities now face similar problems, and the creation of institutions which facilitate transnational policy learning becomes an important strategy in developing and disseminating new policy concepts (Kern, 2001).

\section{Transnational Municipal Networks in the Area of Climate Change}

Three networks have emerged in the area of climate change policy in Europe since the early 1990s: the Climate Alliance, Cities for Climate Protection and Energie-Cités. Almost 1,400 European cities and towns, including many capital cities, such as Amsterdam, Rome, Stockholm and Berlin, have joined at least one of these networks. ${ }^{3}$ Both striking similarities and pronounced differences emerge from a comparison of the three transnational networks. First, all three networks were created in the early 1990s shortly before the United Nations Conference on Environment and Development (UNCED) in Rio de Janeiro in 1992, which put climate protection policy on the global, European and national political agendas. Whereas all three networks have climate protection policy as their respective raisons d'être, each network was

\footnotetext{
${ }^{3}$ With around 1,100 full members in 17 European countries, the Climate Alliance, whose European headquarters are located in Frankfurt am Main, is by far the largest of these networks. Cities for Climate Protection (CCP) is an ICLEI initiative - a global TMN co-ordinated on a regional basis. ICLEI was founded as the International Council for Local Environmental Initiatives in 1990; today it is known as Local Governments for Sustainability. The ICLEI-Europe headquarters and CCP-Europe are based in Freiburg, Germany. CCP-Europe comprises about 120 members in 16 European countries. Energie-Cités has over 160 individual members in 25 European countries and has its headquarters in Besançon, France. It has run its own office in Brussels for several years and has been sharing it with the Climate Alliance since 2007 (all data for 2008).
} 
established and developed on the basis of considerably different underlying reasons: Energie-Cités stemmed from a project funded by the EU Commission; the Climate Alliance developed bottom-up and still displays the traits of an NGO; and Cities for Climate Protection (CCP) is a global city network with a European branch, CCP-Europe (Bennington and Harvey, 1998, p. 159).

Second, the general goals of the networks are almost identical. The networks seek voluntary commitments from municipalities for the reduction of greenhouse gas emissions, they try to enhance local capacities for addressing climate change, they promote the exchange of experience and transfer of know-how among their member cities and they represent the interests of their constituents at national, supranational and international level. The methods used by each network differ from those used by the others, with the differences between the Climate Alliance and the Cities for Climate Protection being most striking.

Third, after very dynamic phases of growth it appears that all three networks have stabilized (Straßheim and Oppen, 2006). There are some differences between the networks regarding their membership structure. The Climate Alliance created the status of associated members, which are mainly regions and NGOs; Energie-Cités has energy agencies and public utilities among its membership; and Cities for Climate Protection consists exclusively of municipalities. With regard to the size of the cities involved in the networks, the members of the Climate Alliance include not only large metropolitan areas but also many small and medium-sized towns and cities.

Fourth, in terms of the presence of the networks in different countries, a clear territorial pattern has emerged (see Figure 2). Language appears to be a crucial issue here: for example, the Climate Alliance faces serious problems in expanding to certain countries (such as the UK or France) because the network's main working language is German. Although the Climate Alliance is by far the largest TMN in the area of climate protection in Europe, most of its member cities are located in continental Europe (Germany, Austria and the Netherlands). Most of the members of Cities for Climate Protection, an English-speaking network, are located in Finland and the UK where they run national campaigns. Energie-Cités, which has chosen English and French as working languages, has its stronghold in France. Since it has become difficult to find new members in the old Member States of the European Union, all three networks have begun to orient their activities towards central and eastern Europe where potential member cities are easier to find. This development can also be regarded as a dimension of Europeanization (Olsen, 2002; Schimmelfennig and Sedelmeier, 2005) as TMNs have begun to adapt to EU enlargement by extending their activities to the new EU Member States. 
Figure 2: Members of Transnational Municipal Networks in the Area of Climate Change Policy in Europe

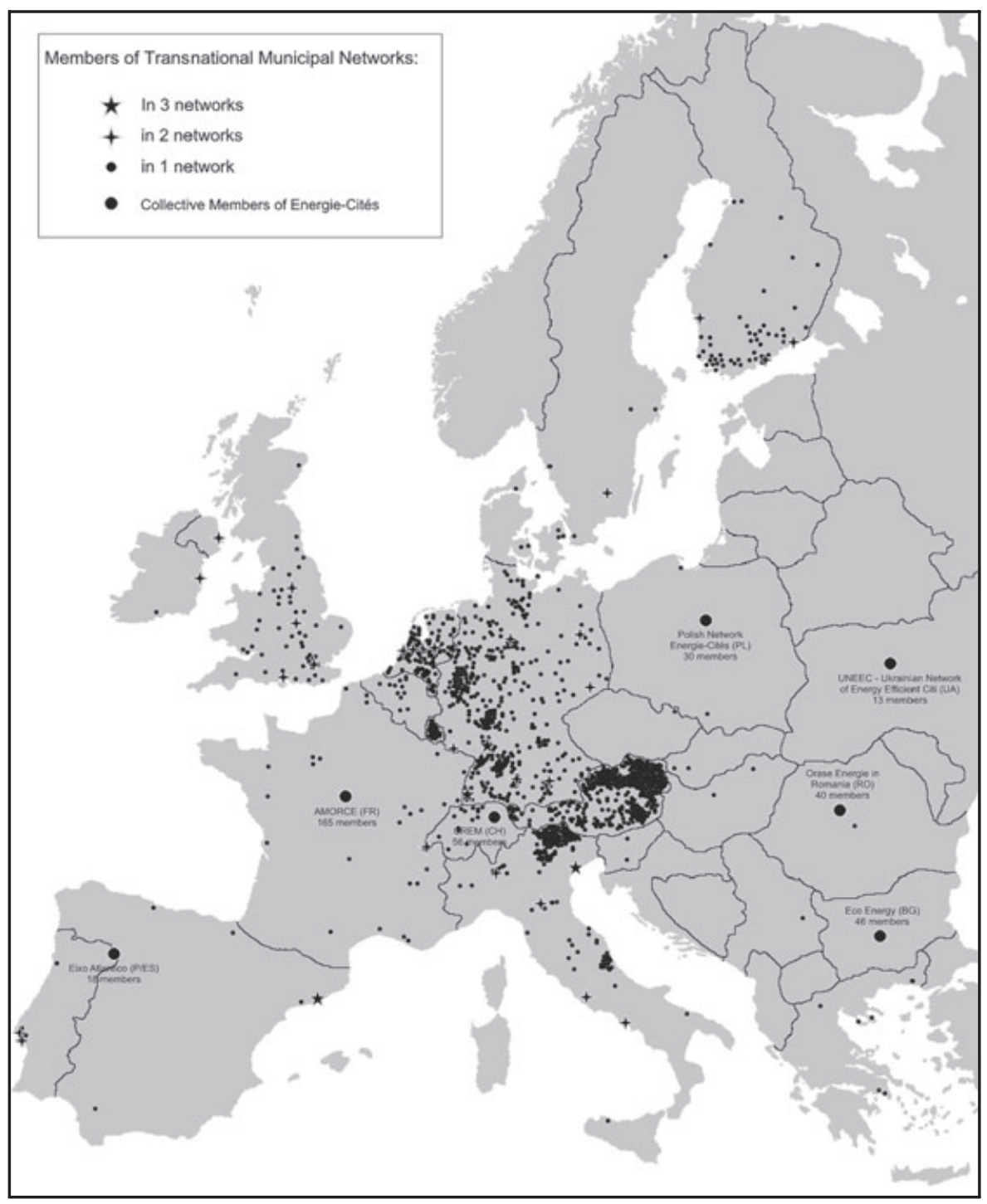

Source: Authors' own data. 
Fifth, all three networks have a decentralized organizational structure. The Cities for Climate Protection conduct national campaigns (in the UK, Finland and Italy), the Climate Alliance has national co-ordination offices (e.g. in Italy, Austria, the Netherlands and Luxembourg) and Energie-Cités has established relatively independent national sub-networks (in France, Bulgaria, Romania, Poland and the Ukraine). Within such structures, TMNs face the challenge that they cannot use hierarchical authority to achieve the overall network goals. Instead they must develop new modes of governing and it is to these issues that we shall now turn.

\section{Governing Climate Change through Transnational Municipal Networks}

Based on our empirical case studies, we find that TMNs have developed forms of governing, through which they seek to influence both the nature of the debate concerning climate protection and actions focused on this objective. First, TMNs engage in various strategies of internal governing. Second, in order to operate efficiently within a multi-level governance context (see Figure 3), TMNs adopt various approaches of external governing, namely influence, interdependence and intermediation. These forms of internal and external governing are not unique features of the type of networks analysed here in more detail (Triantafillou, 2007). They are also characteristic of other TMNs, for example Eurocities and the Union of the Baltic Cities (Kern, 2001; Joas et al., 2007).

\section{Internal Governing: From Information Dissemination to Certification?}

Internal (intraorganizational) governing is a form of self-governance, which aims to recruit new members, stabilize the network and achieve network goals through member cities. In the absence of the usual forms of authority afforded to governmental actors in hierarchical relations of power - i.e. regulation, sanction and force - networks rely on other forms of authority and persuasion. The secretariat, along with leading cities in the network, plays a critical role in orchestrating and enforcing mechanisms of internal governing. Based on our analysis of climate protection networks in Europe, we would suggest that there are three core strategies deployed for internal governing: (1) information and communication; (2) project funding and co-operation; and (3) recognition, benchmarking and certification.

Strategies of information and communication are the bread and butter of TMNs. Networks are frequently established for the explicit purpose of creating and sharing 'best' or 'good' practice, and municipalities indicate that the 
Figure 3: Governing Capacities of Transnational Municipal Networks

\section{Transnational Municipal Network (TMN)}

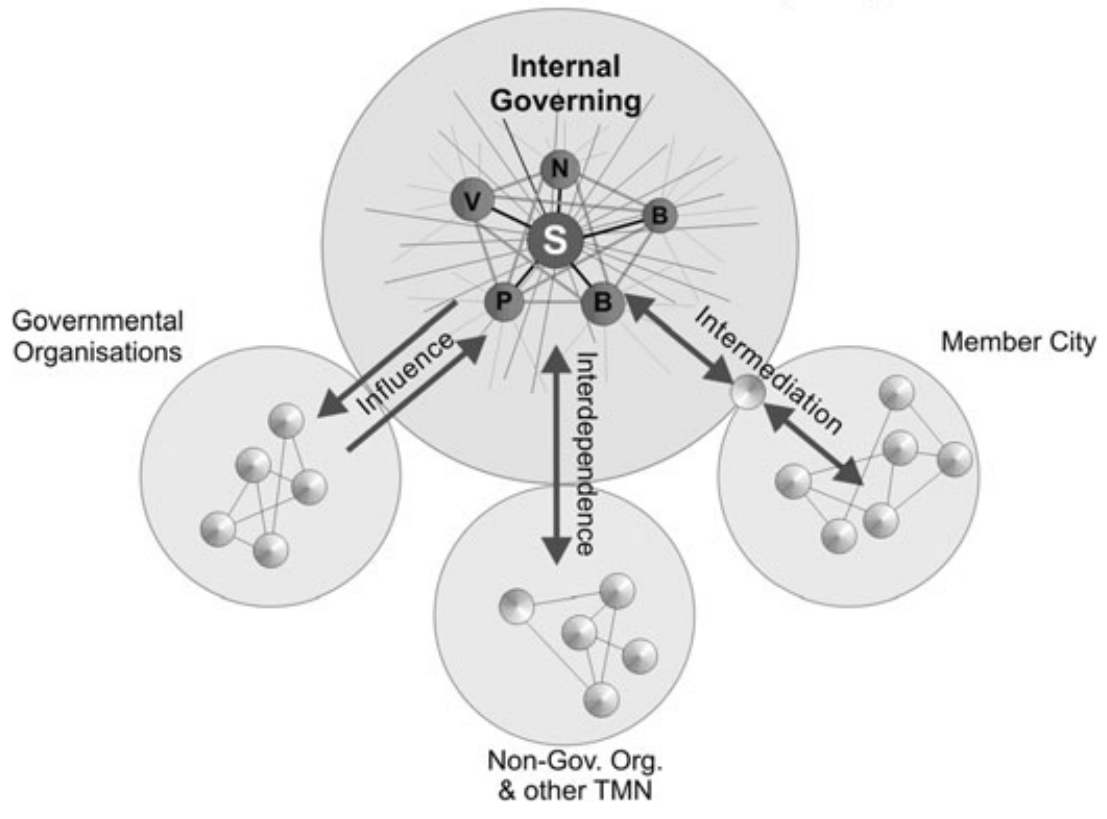

Source: Authors' own data.

opportunity to learn about 'what works' from other places is a key motivation for their participation in networks. For example, Energie-Cités stated that it acts as a conduit for the flow of information and examples through their online good-practice database, the dissemination of good-practice CD-ROMs, the circulation of a newsletter and the organization of 'study tours' where groups of local officials and politicians can arrange to visit a city in Europe to learn at first hand how local energy policies were created (Energie-Cités, 2007). CCP-Europe produces good-practice case studies and the Climate Alliance has pursued a similar strategy, developing a best practice database and disseminating information on best practice which is published regularly in its newsletter ('project of the month').

There are, however, two challenges confronting networks which employ such strategies for internal governing. First, in the selection and production of good- or best-practice models, networks go to different lengths to develop case studies and examples, from simply gathering evidence and ideas from members and other sources to proactively developing good practices with municipalities. This laissez-faire approach ensures that a variety of examples 
are available and that the evidence comes from the bottom up, but it provides little guarantee of the quality, replicability and transferability of such examples. The resulting models may thus be 'sanitized'; members of municipalities spoke frequently of the need to get behind the official storylines of best practice in order to find the real story if any form of implementation was to follow (Bulkeley, 2006). The second challenge posed by the use of strategies of information and communication for internal governing lies precisely in the process of uptake. As the networks have recognized, while municipalities are keen to be involved in the production of best practice, there is less evidence that best practice is actually taken up and acted on in a direct sense. Instead, it is often merely used as a source of inspiration or device for persuading others of the merits and potential of acting locally.

A more direct approach to internal governing used by the networks involves project funding and co-operation. Transnational projects are seen by the networks as a crucial means by which to improve municipal performance with respect to climate protection. Networks seek to facilitate this process either by providing means through which members can contact each other in order to bid jointly for (usually EU) project funding, or by submitting bids themselves together with their constituent municipalities. For example, three German cities, Stuttgart, Bremen and Dresden, have been involved through $C C P$-Europe in a project to examine the hidden subsidies given to motorized private transport through local authority spending (CCP-Europe, 2004). Recent projects which Energie-Cités have been involved in include, for example, BELIEF (Building in Europe Local Intelligent Energy Forums) which is co-financed by the European Commission under the Intelligent Energy Europe programme. EU-funded projects, such as the co-ordination and evaluation of the European Mobility Week (Climate Alliance, 2007), have become increasingly important for the Climate Alliance.

This strategy of internal governing works in two ways: first, it serves to tie member municipalities more closely together through day-to-day dealings on projects and to enhance these cities' connection to the network upon which they are reliant for access to resources to carry out particular projects. Second, this kind of governing strategy assists networks in achieving their goals on the ground by providing additional financial resources to enable local action, which is not (necessarily) reliant on acquiring local resources and accessing local networks. However, it is also a strategy which has limited effect across the network. The process of applying for and delivering such projects is resource-intensive and therefore primarily attracts the most active and established members of TMNs. To a certain extent, rather than being a strategy of engaging the membership as a whole, a project-based strategy of internal governing serves to further cement the core of the network. 
Recognition, benchmarking and certification entail more interventionist approaches to internal governing which may be able to reach beyond the network core. Strategies of recognition involve offering various types of rewards for performance, including the listing of a municipality as an example of good practice or creation of a competition for specific awards. The Climate Alliance has developed the 'Climate Star' award for municipalities across Europe and, in 2004, of a total of 203 entries of local authorities from 17 countries, 22 municipalities received recognition for their efforts in the area of renewable energy (Climate Alliance, 2005, p. 27). While such schemes are clearly important to both the networks and their members, only a limited number of municipalities can be recognized and this again tends to offer incentives to already active cities rather than affecting the behaviour of the more passive cities. Benchmarking is another performance-based strategy but one which has clearly defined standards and which seeks to involve all network participants. From its inception the $C C P$ network has relied on a series of benchmarks or milestones of municipal progress (Bulkeley and Betsill, 2003). The milestone approach involves conducting an emissions inventory, setting an emissions reduction target, formulating an action plan, implementing policies and monitoring progress. The Climate Alliance has developed an alternative approach. Its climate protection methodology for monitoring progress consists of an action list referred to as the '10 Steps', the 'Catalogue of Measures' and the 'Climate Alliance Indicators'. Such approaches can offer a useful means by which the secretariat and members can gauge improvement and on the basis of which climate protection policy development can be standardized and implemented locally. More interventionist approaches such as certification have been developed and tested at national level, for example, in Switzerland. Over 160 Swiss municipalities have been certified by an independent commission and have been awarded the label 'Energiestadt Schweiz' (Swiss Energy City), based on the implementation of at least 50 per cent of possible measures. Moreover, national experiences in Switzerland, Austria and the German Federal State of North Rhine-Westphalia have led to the development of a European scheme, the 'European Energy Award' (EEA). ${ }^{4}$

Although the more interventionist approaches such as benchmarking and certification create peer pressure which appears to be a powerful tool in promoting compliance, particularly among laggards (Lehtonen, 2005), all three networks have only used such approaches to a limited extent. It would appear that neither the above-mentioned national approaches nor the

\footnotetext{
${ }^{4}$ The European Energy Award was developed within the 5th EU Framework Programme for Research and Technological Development (RTD). Currently the IEE (Intelligent Energy Europe) project, BALANCE, extends the implementation of the programme to include other European countries and regions.
} 
development of the European Energy Award had an impact on the three networks which still pursue their own 'softer' approaches. Interventionist strategies are difficult to implement because TMNs lack the authority to force their members to participate in benchmarking or certification exercises and to impose sanctions on their members if necessary. ${ }^{5}$ Thus, certification is still confined to the most active cities which have already launched many local initiatives in the area of climate change policy and want to demonstrate their progress. For the most active members of the network, the costs outweigh the benefits from a positive image associated with certification.

Each of the strategies for internal governing - information and communication; project funding and co-operation; recognition, benchmarking and certification - pose their own challenges. At one end of the spectrum the more laissez-faire approaches like information and communication are appealing in that they demand fewer network resources and less intervention, but this is countered by less certainty at network level as to what is being achieved and for whom. At the other end of the spectrum the more interventionist approaches can lead to an exclusive focus on the most active municipalities in the network, alienating the rest who may not be able to commit themselves to, or fit in with, the network ethos.

\section{External Governing in a Multi-Level Context: Influence, Interdependence and Intermediation}

The success of TMNs in the European multi-level system depends not only on internal governing capacities, but on creating the conditions for successful intervention by municipalities with respect to climate change. This involves seeking to influence governmental actors, forms of interdependence with non-governmental actors and other TMNs and strategies for intermediation between actors at the network level and at the municipal level (see Figure 3). Here we consider how the three climate change networks have engaged with each of these activities in turn.

TMNs influence governmental organizations at different levels. Within the international climate change regime, climate change networks have been granted observer status and hold side events to publicize the achievements of their members and the possibilities for taking action at the annual Conference of the Parties. Through these activities the networks, in particular the Cities for Climate Protection and the Climate Alliance, seek to persuade the international community to take a more proactive stance on addressing the climate

\footnotetext{
${ }^{5}$ Even such soft forms of benchmarking have some downsides. Benchmarks become harder to implement in the fuzzy world of emissions outside municipalities' direct control, where accounting for emissions, and the effects of particular actions to reduce them, is harder to achieve.
} 
change problem. Given the European focus of the networks under consideration in this article, it comes as no surprise to discover that the European Commission is the focus of considerable attention at international level. The presence of the Energie-Cités office in Brussels bears testament to the emphasis that it places on lobbying European institutions, including the Committee of the Regions as well as the EU Commission and Parliament, as a core network activity. Lobbying is facilitated through personal and frequent contact with individuals in the relevant Directorates General of the Commission as well as through 'lunch discussions' which are held on topical issues at the Energie-Cités office with key officials, member municipalities and partners (Energie-Cités, 2003, p. 7). The network regards itself as offering a 'two-way flow' of information, representing the knowledge and views of its constituents to the Commission and advising its members on the changing legislative and funding contexts. CCP-Europe and the Climate Alliance, in contrast, do not lobby directly but seek instead to influence the Commission by demonstrating what can be achieved through municipal governments. However, they do take advantage of the opportunity structure and access provided by the European Commission, for instance, by participating in stakeholder consultation processes.

In addition to lobbying or participating in consultation processes all three networks strive to obtain financial support for their projects. Although funding by national governments still plays an important role and national governments are critical actors (this is the case especially for CCP-Europe which has established national campaigns), the European Commission has gained considerable influence on the networks, in particular by making project funding available. EU funding has become more important for the daily work of all three networks. Because the membership fees of Cities for Climate Protection Campaign are lower than those of the other networks, it is even more dependent than the others on third-party funding, and about 45 per cent of its revenues come from EU projects. However, even in the case of the Climate Alliance and Energie-Cités membership fees only make up about 30 per cent of the total budget. This means that all three networks depend heavily on governmental funding and to a large degree on European funding, and could not maintain their services and campaigns without these resources. Hence, all three networks not only try to influence the decisions taken at European level, they are also influenced by EU institutions.

The interdependence of TMNs proves significant in this context. Interdependence, that is the co-operation and competition between transnational networks, is of special interest in relation to climate change because, unlike most other areas of sustainable development in Europe, three networks are active in this particular field. Networks have in the past competed for 
members, but as they have established their membership in different countries (largely on the basis of languages for the Climate Alliance and Energie-Cités and through a focus on larger cities for $C C P$-Europe) competition has eased. There are only a few European countries, i.e. in particular Germany, the UK, Italy and the Netherlands, where at least two or even all three networks are active. However, competition remains a feature of network interdependence as they compete for funding, particularly from the European Commission, and status as the leading European network of municipalities addressing climate change. This competition cannot be explained by overlapping membership. Energie-Cités, which based on our interviews and analysis appears to be the network that has developed co-operative relations with both the other networks, has the highest number of member cities which have also joined at least one other network. In contrast, although only eight cities belong to both the Climate Alliance and the Cities for Climate Protection, the relations between these two networks appear to be most competitive. This may be explained by the fact that they have taken similar approaches to internal governing, but have chosen different methodologies.

Despite the evidence of competition between networks, there is also evidence of co-operation. For example, the Climate Alliance and the EnergieCités network have undertaken joint projects, for example the 'Car Free Day' and 'Mobility Week' campaigns. Co-operation between the networks was enhanced when the board of the Sustainable Cities and Towns Campaign (a body sponsored by the European Commission to facilitate co-operation on urban sustainability issues across Europe) was enlarged and the Climate Alliance and Energie-Cités became members of its board. ${ }^{6}$ While the Campaign had institutional funding from the Commission, the three networks worked closely together within this new institutional framework. This in turn facilitated co-operation between them. One example of a co-operative endeavour which emerged from this more closely knit collaboration was an integrated thematic working session of the Campaign on climate change and energy, which took place in 2002, and was prepared jointly by the Climate Alliance and Energie-Cités. After 2003, when the Commission decided to cease funding the Campaign, this institutional framework dissolved. However in that same year, at the request of some of their members, the three networks formed the Climate Task Force of European Local Governments, which was established with the core aim of providing a joint means of lobbying European political bodies about the need for a municipal approach to the climate change problem in Europe. In 2003, the membership of the Climate Task Force comprised the three transnational municipal climate networks and 15

${ }^{6}$ ICLEI was a member of the board from the outset.

(C) 2009 The Author(s)

Journal compilation (c) 2009 Blackwell Publishing Ltd 
municipalities; by September 2003 it met at the European Parliament to lobby on issues of co-generation, eco-design, energy services and the implementation of the Electricity Directive. Since that time, however, there has been little evidence of activity on the part of the Climate Task Force, although there were calls at the Climate Alliance's 2005 conference for the reinvigoration of the network taskforce through co-operation with Energie-Cités and the CEMR. Thus, it has proven relatively difficult to maintain co-operation between the networks in the absence of EU support. However, the development towards co-operation and convergence can be supported by the member cities. Some cities (such as Heidelberg and Leicester), which are members of several networks, have advocated closer working relations between networks so that they can assume a more effective lobbying role in Europe.

For the municipalities themselves, the impact and influence of a network is critically dependent on the nature of the intermediation between that network and the broader local policy networks focusing on climate change (Bulkeley and Betsill, 2003). In terms of the network governing capacity, the position of a city within a network is not the only critical factor because the relationship between the 'intermediary' actor and the local policy network is equally important. If the intermediary actor is influential within the local policy network, there is a better chance that transnational network initiatives will be picked up and implemented within the city. Political support at local level and the existence of policy entrepreneurs are, therefore, crucial for the governing capacity of a network because they have a decisive influence on the changes on the ground and provide the means through which the network assesses progress. If such policy entrepreneurs are missing or marginalized, it is almost impossible for the network to stimulate action on the ground. Thus, due to variations in the position of intermediary actors, membership of a network does not necessarily lead directly to action on the ground.

Some network members are highly active locally and transnationally, holding influential positions within their respective municipalities and as members of the boards of TMNs. This tends to be the case in the 'pioneer' municipalities - i.e. those which joined networks in the early stages of their development and have taken an active role in network evolution. Such pioneers contribute to the networks, for example, when they present their own experiences, but they also benefit from the networks because they gain new ideas, access to funding and legitimacy at local level. Membership fees are not considered as a problem among pioneers because they pay off when the municipalities participate in a project financed by the European Commission. In both the UK and Germany the pioneers involved in our research project adopted the position that the benefits of membership appear to outweigh any costs, a position reinforced by the fact that most pioneers are members of 
more than one network and use the specific services which each of these networks provides. In terms of the most important network services, the cities mention exchange of information and experience, facilitation of contacts, assistance regarding EU proposals and project co-ordination and lobbying activities, in particular in Brussels (Kern et al., 2005, pp. 85-86).

Passive network members, by contrast, often lack the financial, human and political resources required to participate in network activities such as conferences, funding bids and the implementation of network benchmarks. Intermediary actors may have a relatively marginal position within local policy networks, having joined such networks at a time when there was more political support for climate change action. By the same token, without proven success - in terms of recognition or funding from the network changing the status of TMNs locally is difficult to achieve. A negative spiral can be established whereby passive membership leads to few rewards which in turn leads to greater political marginalization. However, even in relatively passive municipalities, membership is frequently used by the few climate change advocates as a source of external legitimacy and inspiration (Bulkeley and Betsill, 2003; Kern et al., 2005). This helps them to maintain their activities even in situations characterized by financial stress, political disinterest or active opposition to local action for climate mitigation.

The three elements of external governing discussed above, i.e. influence, interdependence and intermediation, are intertwined. First, the influence of TMNs depends on the interdependent relationships between networks. If competition between networks dominates, networks will find it difficult to influence European institutions. Conversely, both co-operative and competitive behaviour between networks can be influenced by the EU, in particular the Commission. Rivalry between TMNs increases when networks compete for EU funding, while co-operation between them can be facilitated by EU initiatives specifically aimed at network co-ordination, such as the funding of the European Sustainable Cities and Towns Campaign. Second, the interdependent relationships between TMNs are affected by the intermediation between a network and its members. The pioneering cities, which are most often members of several networks, may push competing networks or competing secretariats towards a more co-operative mode of interaction. An example of this is the common taskforce of all three networks, founded to improve lobbying activities at the European level. Third, the intermediation between a network and its members has repercussions for the cities' opportunities to influence and be influenced by European institutions. Direct relations between EU institutions and cities are usually restricted to the most active cities which hold important positions in the network, such as the presidency or vice-presidency, representing the network externally. 


\section{Conclusion}

Overall, our results suggest that the forms of governing which TMNs employ are critical for their success. TMNs have developed a range of strategies for coping with the multi-level governance context of the EU. Their emergence and development can be considered as emblematic of the dynamic of Europeanization, i.e. being influenced by EU structures and institutions while seeking to influence them. Although our findings are primarily based on the analysis of three climate change networks, the development of other TMNs, such as Eurocities or the Union of the Baltic Cities, suggests similar developments in other policy areas (Kern, 2001; Joas et al., 2007; Keiner and Kim, 2007; Heinelt and Niederhafner, 2008). TMNs provide a means through which the Commission can seek to achieve policy goals on the ground without necessarily having to engage directly with nation-states. Whether such networks reach their goals or fail to do so will depend on how they are affected by Europeanization.

Three dimensions of the Europeanization of local authorities can be identified here: first, top-down (vertical) Europeanization is the most obvious form because cities are increasingly affected by European regulations which they are required to implement. Our research shows that hierarchical structures wherein local authorities which are located in specific nation-states interact directly only with these are supplemented by direct relations between local authorities and European institutions, in particular the Commission. Second, bottom-up (vertical) Europeanization has developed as a reaction to the increasing significance of EU initiatives for the local sphere, including the development of TMNs, which represent their member cities in Brussels. Third, horizontal Europeanization has become a common feature of local authorities' interaction in the European multi-level system. Cities learn from one another when they jointly develop solutions for shared problems; they compete with one another when they engage in benchmarking exercises or vie for awards for their local activities.

The governing capacities of TMNs are critical to the networks' success. The three networks analysed here have not adopted interventionist approaches but have assumed more laissez-faire approaches instead. Although certification of member cities is the most promising innovation designed to improve internal governing, it has been applied only by national municipal networks. The governing capacities of TMNs are limited because they do not have the authority to force their members to apply specific strategies at the local level, nor do they have the authority to control and sanction their members. These laissez-faire approaches, based on soft governing tools, reinforce differing patterns of network participation between 
leaders and laggards. In effect, our findings suggest that networks are networks of pioneers for pioneers. Even among the cities which deliberately joined a network it is easy to distinguish between a hard core of pioneers and a periphery consisting of relatively passive cities which have scarcely changed their behaviour since joining the network. While top-down (vertical) Europeanization has similar effects on all European cities and towns, because in many EU Member States local authorities are in charge of implementing European legislation, bottom-up (vertical) Europeanization, which facilitates the upload of innovative ideas and increases the autonomy of sub-national actors, and horizontal Europeanization among the most active member cities are clearly still privileges of the pioneers.

\section{Correspondence:}

Harriet Bulkeley

Durham University, UK

email h.a.bulkeley@durham.ac.uk

Kristine Kern

Wageningen University, The Netherlands

email kristine.kern@sh.se

\section{References}

Bache, I. (2008) Europeanization and Multi-level Governance (Lanham, MD: Rowman \& Littlefield).

Bache, I. and Flinders, M. (eds) (2004) Multi-level Governance (Oxford: Oxford University Press).

Baumgartner, F. and Jones, B. (1993) Agendas and Instability in American Politics (Chicago, IL: University of Chicago Press).

Bennington, J. and Harvey, J. (1998) 'Transnational Local Authority Networking within the European Union: Passing Fashion or New Paradigm?' In Marsh, D. (ed.) Comparing Policy Networks (Buckingham: Open University Press).

Betsill, M. and Bulkeley, H. (2004) 'Transnational Networks and Global Environmental Governance: The Cities for Climate Protection Program'. International Studies Quarterly, Vol. 48, pp. 471-93.

Birkland, T. (2007) 'Agenda Setting in Public Policy'. In Fischer, F., Miller, G. and Sidney, M. (eds) Handbook of Public Policy Analysis (Boca Raton: Taylor \& Francis).

Börzel, T. (1998) 'Organizing Babylon: On the Different Conceptions of Policy Networks'. Public Administration, Vol. 76, pp. 252-73.

Börzel, T. and Risse, T. (2007) 'Europeanization: The Domestic Impact of European Union Politics'. In Jørgensen, K., Pollack, M. and Rosamond, B. (eds) Handbook of European Union Politics (London: Sage). 
Bulkeley, H. (2006) 'Urban Sustainability: Learning from Best Practice?' Environment and Planning A, Vol. 38, No. 6, pp. 1029-44.

Bulkeley, H. and Betsill, M. (2003) Cities and Climate Change: Urban Sustainability and Global Environmental Governance (London: Routledge).

Bulkeley, H. and Kern, K. (2006) 'Local Government and the Governing of Climate Change in Germany and the UK'. Urban Studies, Vol. 43, No. 12, pp. 2237-59.

CCP-Europe (2004) Themes: Climate and Air (Freiburg).

Climate Alliance (2005) Annual Report 2004/2005 (Frankfurt/Main).

Climate Alliance (2007) Activity Report (Frankfurt/Main).

Eising, R. (2004) 'Interest Groups and the European Union'. In Cini, M. (ed.) European Union Politics (Oxford: Oxford University Press).

Energie-Cités (2003) 'Info-Bulletin', No. 26, Energie-Cités.

Energie-Cités (2007) 'Info-Bulletin', No. 33, Energie-Cités.

Ercole, E., Walters, M. and Goldsmith, M. (1997) 'Cities, Networks, Euregions, European Offices'. In Goldsmith, M. and Klausen, K.K. (eds) European Integration and Local Government (Cheltenham: Edward Elgar).

Ewen, S. and Hebbert, M. (2007) 'European Cities in a Networked World during the Long 20th Century'. Environment and Planning C: Government and Policy, Vol. 25, pp. 327-40.

Featherstone, K. and Radaelli, C. (eds) (2003) The Politics of Europeanization (Oxford: Oxford University Press).

Goldsmith, M. (2003) 'Variable Geometry, Multi-level Governance: European Integration and Subnational Government in the New Millennium'. In Featherstone, K. and Radaelli, C. (eds) The Politics of Europeanization (Oxford: Oxford University Press).

Graziano, P. and Vink, M. (eds) (2007) Europeanization: New Research Agendas (Houndmills: Palgrave Macmillan).

Haas, P., Keohane, R. and Levy, M. (eds) (1993) Institutions for the Earth: Sources of Effective Environmental Protection (Cambridge, MA: MIT Press).

Heinelt, H. and Niederhafner, S. (2008) 'Cities and Organized Interest Intermediation in the EU Multi-level System'. European Urban and Regional Studies, Vol. 15, No. 2, pp. 173-87.

Hooghe, L. and Marks, G. (2003) 'Unraveling the Central State? Types of Multi-level Governance'. American Political Science Review, Vol. 97, No. 2, pp. 233-43.

Joas, M., Kern, K. and Sandberg, S. (2007) 'Actors and Arenas in Hybrid Networks: Implications for Environmental Policy-Making in the Baltic Sea Region'. Ambio, Vol. 35, No. 3, pp. 237-42.

John, P. (2000) 'The Europeanization of Sub-national Governance'. Urban Studies, Vol. 37, No. 5-6, pp. 877-94.

Kassim, H. (2005) 'The Europeanization of Member State Institutions'. In Bulmer, S. and Lequesne, C. (eds) The Member States of the European Union (Oxford: Oxford University Press).

Keck, M. and Sikkink, K. (1998) Activists beyond Borders. Advocacy Networks in International Politics (Ithaca, NY: Cornell University Press). 
Keiner, M. and Kim, A. (2007) 'Transnational City Networks for Sustainability'. European Planning Studies, Vol. 15, No. 10, pp. 1369-95.

Kern, K. (2001) 'Transnationale Städtenetzwerke in Europa'. In Schröter, E. (ed.) Empirische Policy- und Verwaltungsforschung. Lokale, nationale und internationale Perspektiven (Opladen: Leske + Budrich).

Kern, K. and Löffelsend, T. (2008) 'Governance beyond the Nation State: Transnationalization and Europeanization of the Baltic Sea Region'. In Joas, M., Jahn, D. and Kern, K. (eds) Governing a Common Sea: Environmental Policies in the Baltic Sea Region (London: Earthscan).

Kern, K., Niederhafner, S., Rechlin, S. and Wagner, J. (2005) Kommunaler Klimaschutz in Deutschland - Handlungsoptionen, Entwicklung und Perspektiven. WZB Discussion Paper SP IV 2005-101, Berlin.

Khagram, S. and Ali, S. (2008) 'Transnational Transformations: From Government-Centric Interstate Regimes to Cross-sectoral Multi-level Networks of Global Governance'. In Park, J., Conca, K. and Finger, M. (eds) The Crisis of Global Environmental Governance (London/New York: Routledge).

Kingdon, J. (2003) Agendas, Alternatives and Public Policies (New York: Longman).

Ladrech, R. (2005) 'The Europeanization of Interest Groups and Political Parties'. In Bulmer, S. and Lequesne, C. (eds) The Member States of the European Union (Oxford: Oxford University Press).

Lehtonen, M. (2005) 'OECD Environmental Performance Review Programme. Accountability (f)or Learning?' Evaluation, Vol. 11, No. 2, pp. 169-88.

Leitner, H. and Sheppard, E. (2002) 'The City is Dead, Long Live the Net: Harnessing European Interurban Networks for a Neo-liberal Agenda'. Antipode, Vol. 34, No. 3, pp. 495-518.

Le Galès, P. (2002) European Cities. Social Conflicts and Governance (Oxford: Oxford University Press).

Marshall, A. (2005) 'Europeanization at the Urban Level: Local Actors, Institutions and the Dynamics of Multi-level Interaction'. Journal of European Public Policy, Vol. 12, No. 4, pp. 668-86.

Marshall, A. (2008) 'Local Governance'. In Bache, I. and Jordan, A. (eds) The Europeanization of British Politics (Houndmills: Palgrave Macmillan).

Mintrom, M. (2000) Policy Entrepreneurs and School Choice (Washington, DC: Georgetown University Press).

Olsen, J. (2002) 'The Many Faces of Europeanization'. JCMS, Vol. 40, No. 5, pp. 921-52.

Pattberg, P. (2007) Private Institutions and Global Governance: The New Politics of Environmental Sustainability (Cheltenham: Edward Elgar).

Pierre, J. and Peters, B.G. (2000) Governance, Politics and the State (Houndmills: Macmillan).

Pollack, M. (2005) 'Theorizing the European Union: International Organization, Domestic Polity, or Experiment in New Governance?' Annual Review of Political Science, Vol. 8, pp. 357-98. 
Radaelli, C. (2006) 'Europeanization: Solution or Problem?'. In Cini, M. and Bourne, A. (eds) Palgrave Advances in European Union Studies (Houndmills: Palgrave Macmillan).

Rechlin, S. (2004) 'Die deutschen Kommunen im Mehrebenensystem der Europäischen Union - Betroffene Objekte oder aktive Subjekte?'. WZB Discussion Paper SP IV 2004-101, Berlin.

Repetto, R. (ed.) (2006) Punctuated Equilibrium and the Dynamics of US Environmental Policy (New Haven, CT: Yale University Press).

Rhodes, R. (1997) Understanding Governance: Policy Networks, Governance, Reflexivity and Accountability (Buckingham: Open University Press).

Rosamond, B. (2007) 'New Theories of European Integration'. In Cini, M. (ed). European Union Politics (Oxford: Oxford University Press).

Schimmelfennig, F. and Sedelmeier, U. (eds) (2005) The Europeanization of Central and Eastern Europe (Ithaca, NY: Cornell University Press).

Schultze, C. (2003) 'Cities and EU Governance: Policy-Takers or Policy-Makers?' Regional and Federal Studies, Vol. 13, No. 1, pp. 121-47.

Straßheim, H. and Oppen, M. (2006) Lernen in Städtenetzwerken: Kooperation Konflikte - Kompetenzentwicklung (Berlin: Edition Sigma).

Triantafillou, P. (2007) 'Governing the Formation and Mobilization of Governance Networks'. In Sørensen, E. and Torfing, J. (eds) Theories of Democratic Network Governance (Houndmills: Palgrave Macmillan).

Ward, S. and Williams, R. (1997) 'From Hierarchy to Networks? Sub-central Government and EU Urban Environment Policy'. JCMS, Vol. 35, No. 3, pp. 43964.

Woll, C. (2006) 'Lobbying in the European Union: From Sui Generis to a Comparative Perspective'. Journal of European Public Policy, Vol. 13, No. 3, pp. 456-69.

Zahariadis, N. (2003) Ambiguity and Choice in Public Policy. Political DecisionMaking in Modern Democracies (Washington, DC: Georgetown University Press). 
Copyright of Journal of Common Market Studies is the property of Blackwell Publishing Limited and its content may not be copied or emailed to multiple sites or posted to a listserv without the copyright holder's express written permission. However, users may print, download, or email articles for individual use. 